University of Nebraska - Lincoln

DigitalCommons@University of Nebraska - Lincoln

Notes on South American Dasyomma, with the description of a remarkable new species from Chile (Diptera: Athericidae)

Norman E. Woodley

Smithsonian Institution, norman.woodley@ars.usda.gov

Follow this and additional works at: https://digitalcommons.unl.edu/systentomologyusda

Part of the Entomology Commons

Woodley, Norman E., "Notes on South American Dasyomma, with the description of a remarkable new species from Chile (Diptera: Athericidae)" (2007). USDA Systematic Entomology Laboratory. 75. https://digitalcommons.unl.edu/systentomologyusda/75

This Article is brought to you for free and open access by the Entomology Collections, Miscellaneous at DigitalCommons@University of Nebraska - Lincoln. It has been accepted for inclusion in USDA Systematic Entomology Laboratory by an authorized administrator of DigitalCommons@University of Nebraska - Lincoln. 


\title{
Notes on South American Dasyomma, with the description of a remarkable new species from Chile (Diptera: Athericidae)
}

\author{
NORMAN E. WOODLEY
}

Systematic Entomology Laboratory, PSI, ARS, USDA, c/o Smithsonian Institution NHB-168, P O Box 37012, Washington, DC $20013-$ 7012, USA. E-mail: norman.woodley@ars.usda.gov

\begin{abstract}
A new species of Dasyomma Macquart, D. chrysopilum sp. nov., is described from Chile (Malleco and Nuble Provinces). This species differs from all other known species in having dense golden pilosity on the abdominal tergites of both sexes. Dasyomma basale Malloch is redescribed, with the female described for the first time.
\end{abstract}

Key words: Diptera, Athericidae, Dasyomma, new species, Chile, Bolivia

\section{Introduction}

The genus Dasyomma Macquart is south temperate in distribution, occurring in southern South America, with 20 described species (Coscarón \& Coscarón (1995), and Australia, with 11 described species (Nagatomi \& Evenhuis, 1989). In South America, Dasyomma has only been recorded from Argentina and Chile. However, there is a single female in the National Museum of Natural History, Smithsonian Institution, Washington, DC, USA (hereafter cited as USNM) from Zongo, Bolivia $\left(16^{\circ} 07^{\prime} \mathrm{S}, 68^{\circ} 02^{\prime} \mathrm{W}\right.$ ) that is near $D$. hirticeps Malloch, the first known specimen from Bolivia. It is possible that Dasyomma occurs at high elevation, temperate localities in the Andes farther north than is currently known.

Dasyomma can easily be distinguished from the other New World genera of Athericidae (Atherix Meigen, Suragina Walker, and Xeritha Stuckenberg) by (1) having the eyes densely haired (virtually bare in other genera), (2) the basal part of the antennal flagellum ovoid in lateral view (kidney-shaped in other genera) with the style originating near the apex (dorsal in other genera), (3) the extreme lower margin of the meron above the hind coxa without a deep pit (present in other genera), and (4) the spur on the fore tibia large (minute or absent in other genera). Character states found in Dasyomma for characters 3 and 4, and probably 2, are plesiomorphic and provide evidence that Dasyomma is the most basal lineage of athericids (Stuckenberg, 1973).

Malloch (1932), ever the insightful dipterist, provided an excellent review of the South American species known at the time, based primarily on USNM material and that collected by F. W. and M. Edwards and R. and E. Shannon in 1926 (Edwards, 1929). Malloch discussed characters of probable phylogenetic significance, and recognized three subgenera within Dasyomma. Coscarón \& Coscarón (1995) reviewed the South American species again, incorporating new material, much of which is in the USNM, and described five new species and proposed a few new synonyms.

While curating the USNM collection and incorporating unidentified material I discovered the new species described here. Also, material I collected in Chile included the first known females of $D$. basale Malloch, collected in association with males, which in turn provided some insight into sexual dimorphism in the genus. A redescription is provided for that species as well. 


\section{Dasyomma basale Malloch}

(Figs. 1-4)

Dasyomma basale Malloch, 1932: 226.

Dasyomma atritarsis Malloch, 1932: 234.

Diagnosis. Males of $D$. basale can be distinguished from other described species of Dasyomma by having the following combination of characters: head and thorax black and the abdomen with segments 2-4 yellow with isolated black median spots (Fig. 1), a mostly hyaline wing with a dark cell $r_{1}$ with slight infuscation around the base of the radial veins and discal cell (Figs. 1,2), and bicolored middle and hind femora (Fig. 2). Males key out in the key of Coscarón \& Coscarón (1995) except for difficulty at the first couplet (see remarks below).

Females of $D$. basale can be separated from other described Dasyomma species by having a shiny yellow frons with only indistinct tomentum medially, the scutum entirely yellow, and the wing mostly hyaline with a dark cell $r_{I}$ with slight infuscation around the base of the radial veins and discal cell (Figs. 3, 4) as found in males. Females key readily in the key of Coscarón \& Coscarón to couplet 10, but differ from D. fulvum (Philippi) by having mostly black antennae and the two species that trace through the second half of the couplet because they lack dark medial markings on the scutum.

Description. Male. Overall body coloration black, with extensive yellowish areas on the legs and abdomen (Figs. 1-2).

Head black and appendages black. Eyes holoptic with pale brownish pilosity about the length of antennal scape. Frons, face, and parafacials densely tomentose but without pilosity; frons depressed medially, the depression extending between antennae. Ocellar tubercle, gena and occiput with whitish hairs. Antenna black, base of flagellum with slightly paler color, scape and pedicel with a few dark and pale hairs intermixed. Basal part of antennal flagellum subequal in size to pedicel. Palp black but somewhat yellowish in some (teneral ?) specimens, with pale pilosity, with a few dark hairs in apical part.

Thorax black, thinly, uniformly grayish tomentose. Postpronotal lobes and postalar calli sometimes yellowish or brownish. Scutum and scutellum with uniform long, erect, pale whitish pilosity. Erect, pale pilosity present on propleuron, most of anepisternum, upper part of katepisternum, anterior half of anepimeron and most of laterotergite. Wing mostly hyaline, but with infuscation present distally in cells $c, s c, b r$, and $b m$ and basally in cells $r_{2+3}, r_{5}, d$ and $m_{3}$. Cell $r_{1}$ beyond proximal fork in vein $\mathrm{R}$ (pterostigma of Coscarón \& Coscarón (1995)) brownish black. Veins brownish but pale at base of wing. Tegula dark. Veins $R_{1}$, base of $R_{4+5}$ to just beyond crossvein $\mathrm{r}-\mathrm{m}$, and $\mathrm{CuA}$ nearly to apex of cell $\mathrm{bm}$ with fine black setulae, but can be somewhat reduced and inconspicuous on $\mathrm{CuA}$. Halter with stem yellowish, knob yellowish to dark. Legs black but with mid and hind femora dark yellow on basal two-thirds, front tibia vaguely yellowish on basal half or more, but this coloration not sharply delimited from darker apex, midtibia more conspicuously yellow on basal twothirds, all basitarsi yellowish on basal halves gradually darkening apically. Anterior face of coxae and femora, especially posteriorly, with fine, erect pale pilosity. Tibiae and tarsi with short black vestiture, but sparse, longer, slightly curled hairs present on ventral surface of front tarsus.

Abdomen pale yellow but with entire tergite 1, narrow central spot on tergites 2-4, approximately apical half of segment 5 but with a central, anterior extension medially on tergite, and entire abdomen beyond segment 5 black (tergite 4 more extensively black in apical half in one specimen). Pilosity of abdomen mostly whitish, but black hairs present on medial portions of tergites 2-6. Cercus yellowish brown.

Length $8.0-8.7 \mathrm{~mm}$.

Female. Figs. 3-4. Differs from male as follows: Head completely yellow except for ocellar triangle, antennal pedicel and flagellum, and proboscis which are black; antennal scape brownish. Eyes dichoptic, frons $0.38-0.42$ of head width. Eye pilosity shorter, less than length of pedicel. Frons convex, moderately 
shiny except for very narrow lateral margins that are whitish tomentose; pilosity mostly pale but with some scattered black hairs in upper medial part. Face with wider tomentose margins, medially slightly shiny, mostly bare but a few hairs present medially just below level of antennae. Upper occipital region with dark pilosity. Palp with pale pilosity but with some dark hairs on apical half.

Thorax orangish yellow, with only proepisternum black and some vague darkened areas around anterior and posterior spiracles. Scutum with some dark hairs intermixed with pale pilosity. Tegula with posterior half yellow. Forelegs mostly blackish, but indistinct yellow area on basal, outer region of coxa and basal half of basitarsus. Mid and hind legs with basal half of coxae yellowish, midtibia with some yellowish but not as distinct as in male, otherwise as in male. Some black hairs present on hind femur.

Abdomen dark yellow with segments 5 to apex black, but tergite 5 usually with basomedial area yellowish. Tergites uniformly clothed with dark hairs. Cercus dark yellowish.

Length $5.1-6.8 \mathrm{~mm}$.

Specimens examined. 10 $\Im^{\star}$ CHILE: Malleco Province, Galvarino, 28 November 1929 (USNM; holotype of D. basale Malloch); 20`, CHILE: Valparaiso Province, Perales, January 1925, A. Faz (USNM; holotype and

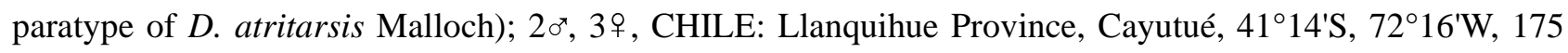
meters, 12 February 1998, N. E. Woodley (USNM); 1ㅇ, same data but 13 February 1998.

Remarks. Five of the specimens cited above that I collected were taken sweeping a tree branch overhanging a small stream. They were all taken at the same time so the males were clearly associated with the females.

All of the species for which both sexes were previously known have coloration that is similar in both sexes. This is the first report for significant sexual dimorphism in color in South American Dasyomma. Because the majority of species are known from only one sex, there is the distinct possibility that there will be additional synonymy when sexes are properly associated. However, this will require further material in which both sexes are taken at the same collecting event. From the material that I have examined of $D$. basale and other species, it appears that the wing infuscation and coloration of the stigma-like marking in cell $r_{l}$ is uniform between the sexes and is useful for identification.

The specimens cited as doubtfully D. basale by Coscarón \& Coscarón (1995: 91) from Chile: Malleco Province, near Los Gringos Camp, Nahuelbuta National Park clearly are not conspecific. As they noted, these specimens have completely dark legs, and the pilosity of the head, including the eyes, is longer and denser. Also, these specimens have the stigma-like mark in cell $r_{l}$ narrower and more elongate, and it is much paler in color than in D. basale. They also lack the infuscation in the region of $\mathrm{r}-\mathrm{m}$ that is present in D. basale. It is possible that these are males of a species described from yellowish females.

I think it is also possible that the male cited by Coscarón \& Coscarón (1995: 93) as D. immaculatum Malloch (erroneously as D. inmaculatum) from the Los Gingos Camp locality noted in the previous paragraph, and the series of females from the same locality cited as D. trivittatum Malloch (Coscarón \& Coscarón 1995: 81 ) are actually the same species. The male differs from $D$. immaculatum by having darker legs and a few setae present on vein CuA. The females differ from Malloch's description of D. trivittatum because none has a trivittate scutum but have a single broad medial vitta that is somewhat variable in width between specimens (and is absent in one). The legs apparently have less yellow on the femora than Malloch noted. All the specimens, including the male, have the extreme base of the mid femur yellowish, up to about one-fifth of its length, and this coloration is present on the fore femur in some specimens. However, the stigma-like marking in cell $r_{l}$ is definitely darker in the male.

The sexual dimorphism found in some species of Dasyomma makes Coscarón \& Coscarón's (1995: 7778) key problematic beyond couplet 10 which separates specimens with a yellow frons and scutum from those with a black frons and scutum. Since some species with mostly yellow females discussed in this paper have males with a black frons and scutum, the females cannot be identified using the key. Also, the pivotal first couplet of Coscarón \& Coscarón's key only works for females. All males I have examined for species that trace to couplet 6 , including $D$. basale, have the small, triangular frons below the contiguous eyes densely 
gray tomentose. The second character used in the couplet, extent of pleural hairing, does not seem to differ as significantly as implied and I have found it very unreliable.

Clearly additional work is needed to resolve the taxonomy of several Dasyomma species. The rather small amount of available material does not allow a clear picture as to whether or not there is geographic variation in such features as leg coloration, which appears to be rather uniform at a single locality. It is unlikely that the species can be adequately understood without significant additional collecting.

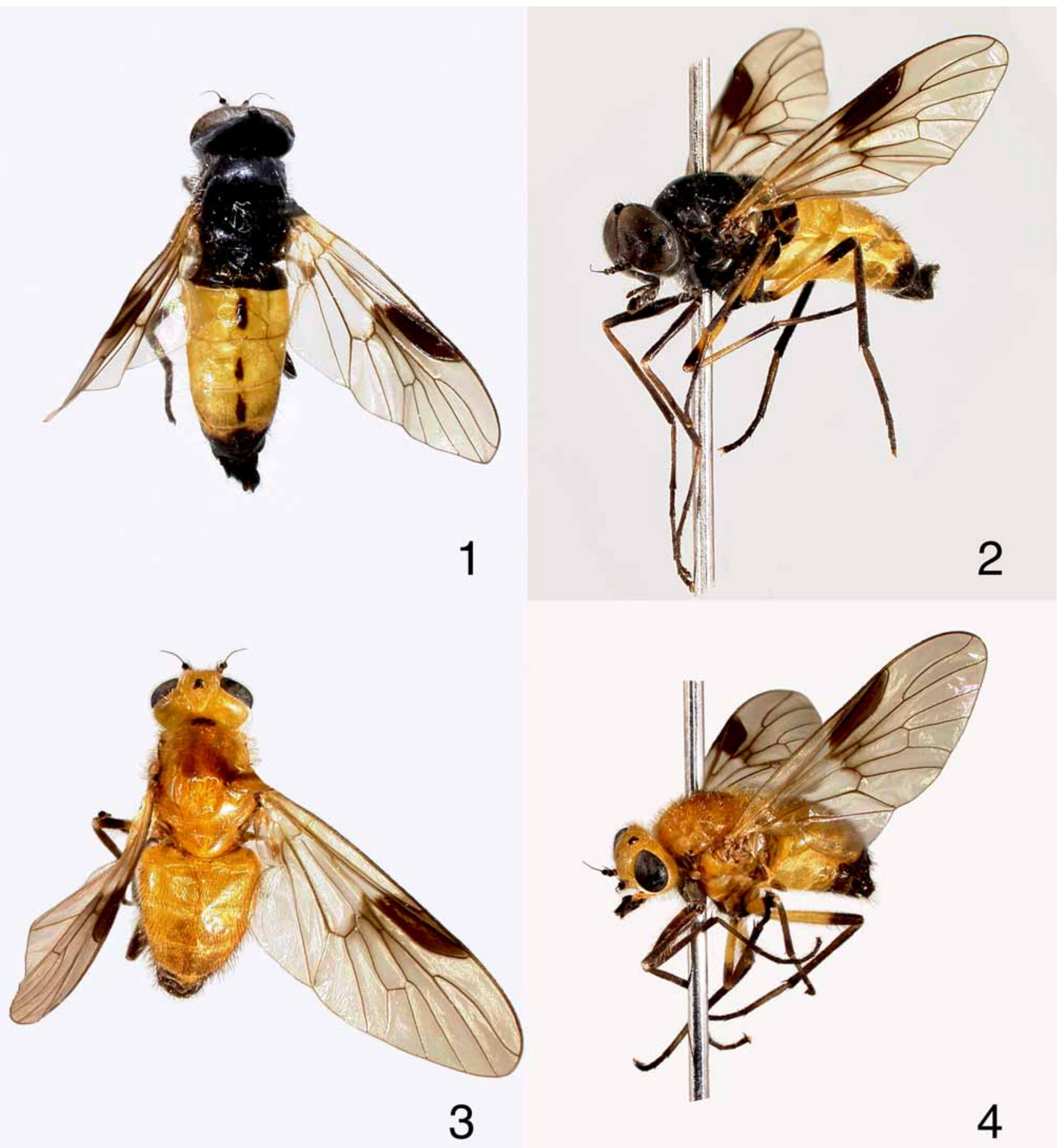

FIGURES 1-4. Dasyomma basale Malloch. 1, male, dorsal view. 2, male, semilateral view. 3, female, dorsal view. 4, female, semilateral view. 


\section{Dasyomma chrysopilum sp. nov.}

(Figs. 5-8)

Diagnosis. Dasyomma chrysopilum sp. nov. can be immediately separated from all other known species of the genus by having dense, semi-appressed golden pilosity on the abdominal tergites (Figs. 5-8), clearly an autapomorphic character state. It fits in the subgenus Dasyomma as recognized by Malloch, as it has fine black setae along vein $\mathrm{CuA}$ where it forms the posterior border of cell bm. In Malloch's (1932) key, D. chrysopilum sp. nov. keys to couplet 2 but then does not fit either half of that couplet because of the abdominal coloration that is black but not at all glossy. In Coscarón \& Coscarón's (1995) key, the female of D. chrysopilum sp. nov. keys to D. fulvum (Philippi), but the male does not key beyond couplet 6 because the body color does not fit either part of the couplet.

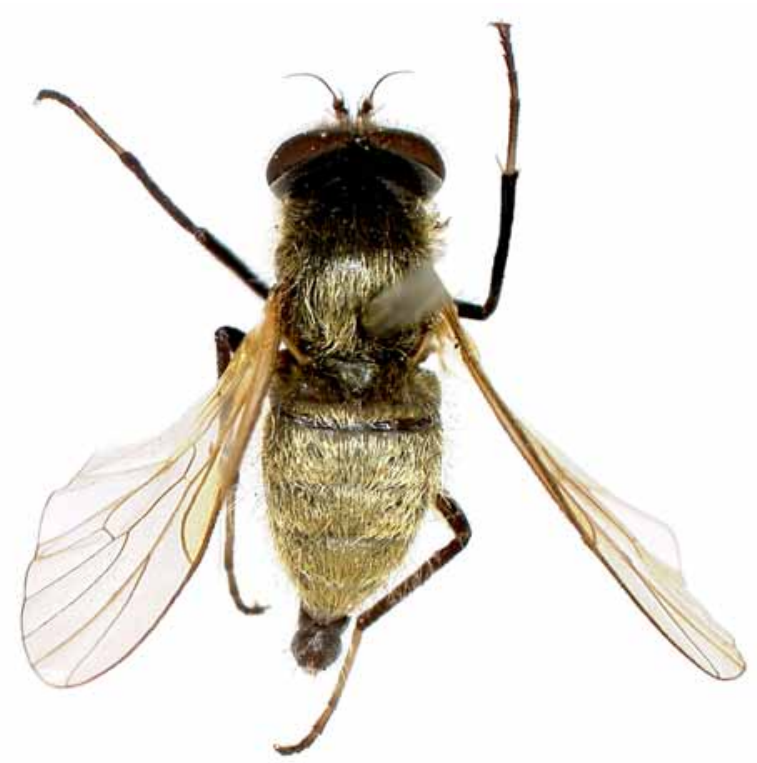

5

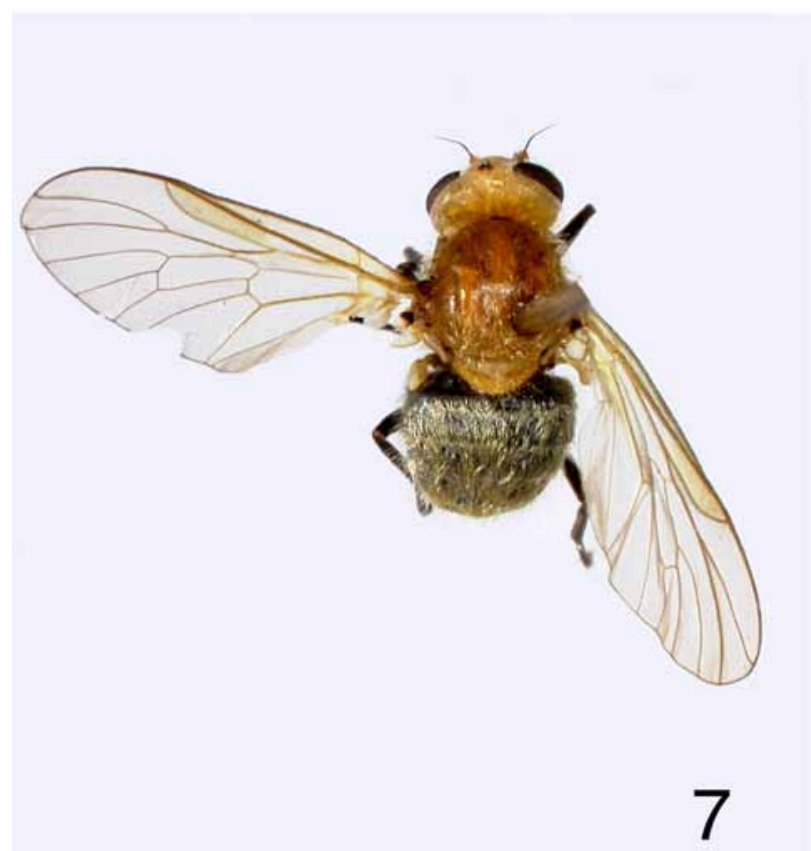

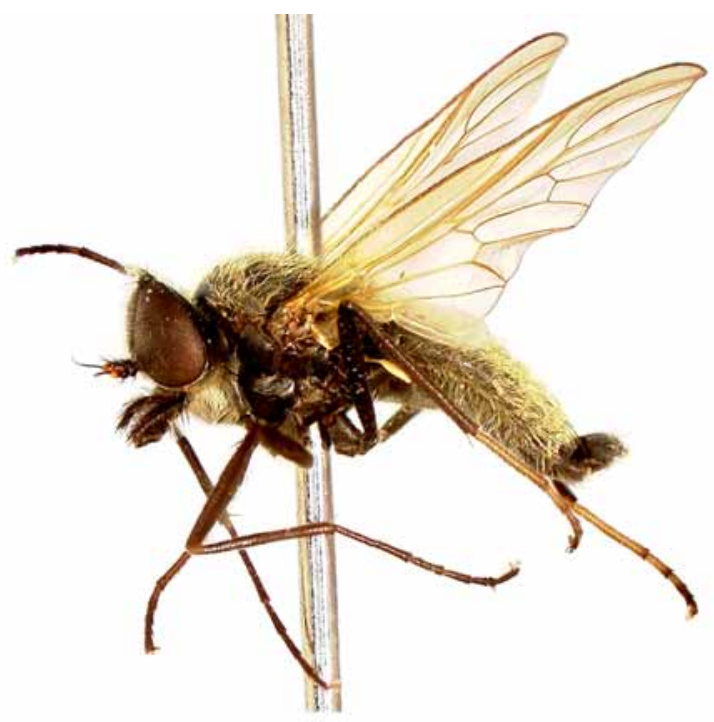

6

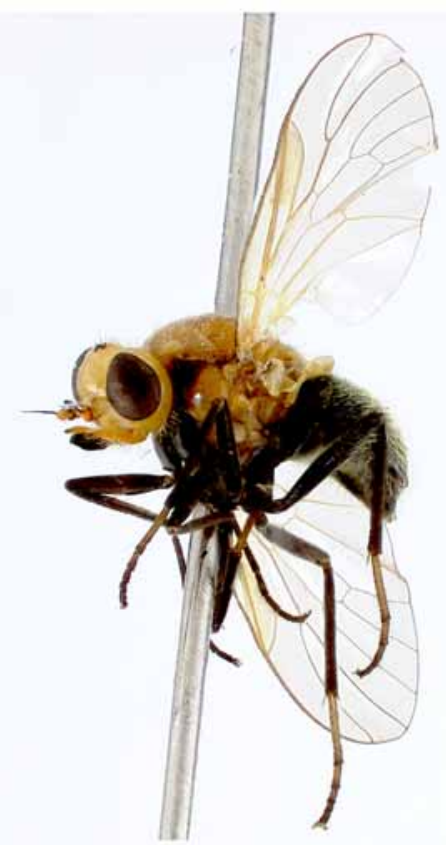

FIGURES 5-8. Dasyomma chrysopilum, sp. nov. 5, male holotype, dorsal view. 6, male holotype, lateral view. 7, female paratype, dorsal view. 8, female paratype, semilateral view. 
Description. Male. General body coloration grayish black, with gray tomentum of varying density present over most of the integument giving an overall grayish appearance with conspicuous pale golden pilosity (Figs. 5-6).

Head and appendages black except for first antennal flagellomere which is bright orangish yellow but usually black on basal one-third. Eyes holoptic with brownish pilosity that is about the length of scape + pedicel. Frons, face, and parafacials densely tomentose but without pilosity; frons depressed medially, the depression extending between antennae. Ocellar tubercle with dark hairs, gena and occiput with pale golden hairs, the latter with a few dark hairs intermixed. Antennal scape and pedicel as well as palp with mostly erect black pilosity, the latter with a few paler hairs sometimes present basally. Basal part of antennal flagellum subequal in size to pedicel.

Thorax with fine, more or less uniform pale gray tomentum not completely obscuring surface. Scutum and scutellum with uniform long, erect, pale golden pilosity, scutum with posterior two-thirds or more also with dense, appressed golden pilosity. Erect, golden pilosity present on propleuron, most of anepisternum, upper part of katepisternum, anterior half of anepimeron and most of laterotergite. Wing hyaline, veins pale yellow, cell $r_{l}$ beyond proximal fork in vein R (pterostigma of Coscarón \& Coscarón (1995)) and anterior part of cell $b r$ yellowish. Tegula black. Veins $\mathrm{R}_{1}$, base of $\mathrm{R}_{4+5}$ to just beyond crossvein $\mathrm{r}-\mathrm{m}$, and CuA nearly to apex of cell bm with fine black setulae. Halter completely pale yellow with only basal region vaguely darker. Legs grayish black, tarsomere 1 and basal part of 2 on midleg, and tarsomeres 1-3 of hind leg, dark yellowish. Anterior face of coxae and femora, especially posteriorly, with fine, erect golden pilosity. Tibiae and tarsi with short black vestiture, but sparse, longer, slightly curled hairs present on ventral surface of front tarsus.

Abdomen completely gray tomentose, tergites 1-6 with long, dense, mostly appressed golden pilosity, more erect laterally, sternites with uniform erect pilosity that is mostly shorter and sparser. Terminalia concolorous with anterior part of abdomen with golden pilosity that has some darker hairs intermixed, circus slightly more yellowish.

Length $5.0-6.5 \mathrm{~mm}$.

Female. Figs. 7-8. Differs from male as follows: Head completely yellow except for ocellar triangle, antennal style, extreme tip of palp, and proboscis which are black; antennal scape and pedicel with slight dark infuscation. Eyes dichoptic, frons 0.38 of head width. Eye pilosity shorter, about as long as pedicel. Frons convex, moderately shiny except for narrow lateral margins that are whitish tomentose, with a small patch of black hairs on each side just above antennal bases. Face with wider tomentose margins, medially slightly shiny, with a few dark and pale hairs medially. Palpi with pale golden pilosity but with a few dark hairs at extreme apex.

Thorax orangish yellow (darker than head), with proepisternum, proepimeron, lower two-thirds of katepisternum and meron, two small spots on anepimeron, metanepisternum and metakatepisternum grayish black. Tegula with posterior half yellow.

Abdomen essentially as in male, but cercus dark yellow.

Length $5.7 \mathrm{~mm}$.

Specimens examined. Holotype $\sigma^{\star}$, CHILE: Malleco Province, Cordillera de las Raices, $40 \mathrm{~km}$ E of Curacautin, 1650 meters, 7-8 February 1979, D. \& M. Davis \& B. Akerbergs (USNM). Paratypes: $1 \sigma^{\rtimes}$, 1 온 same data as holotype (USNM). 10 $0^{\star}$, CHILE: Nuble Province, $6 \mathrm{~km}$ E of Cueva de los Pincheira, approximately 1250 meters, 24-25 January 1999, P. \& M. Hibbs, Malaise trap (USNM).

Etymology. The species epithet refers to the very distinctive golden pilosity present on the abdomen of both sexes.

Remarks. The golden pilosity present on this species is unique among Dasyomma, and gives the species a very distinctive appearance. I have not examined the male genitalia of this species, as this has not been done for most of the described species, but is advisable when the genus is revised in the future. 


\section{Acknowledgments}

Material that I collected and that collected by Peter Hibbs was obtained during field work supported by a National Science Foundation PEET grant (DEB-9521773) to the Smithsonian Institution. Gary Ouellette made the images of the specimens and prepared the plates. Thanks are due to Wayne Mathis (Smithsonian Institution) and Michael Gates and Allen Norrbom (both Systematic Entomology Laboratory) for reviewing the manuscript.

\section{References}

Coscarón, S. \& Coscarón, M.C. (1995) Neotropical Athericidae. II. Revision of genus Dasyomma Macquart 1840 (Diptera: Athericidae). Acta Entomolgica Chilena, 19, 75-98.

Edwards, F.W. (1929) Introduction. Pp. vii-xiv. In: Diptera of Patagonia and South Chile, Part I. British Museum, London, i-xvi + 1-240.

Malloch, J.R. (1932) Rhagionidae. Pp. 199-235. In: Diptera of Patagonia and South Chile, Part V, Fascicle 3. British Museum, London, 199-293.

Nagatomi, A. \& Evenhuis, N.L. (1989) 29. Family Athericidae. In: Evenhuis, N. L. (Ed), Catalog of the Diptera of the Australian and Oceanian Regions. Bishop Museum Press and E. J. Brill, Honolulu and Leiden, p. 295.

Stuckenberg, B.R. (1973) The Athericidae, a new family in the lower Brachycera (Diptera). Annals of the Natal Museum, $21,649-673$. 
